\title{
Early Permian conifer remains from Central Mexico and reevaluation of Paleozoic conifer morphotaxa
}

\author{
Genaro R. Hernández-Castillo, ${ }^{1, *}$, Silvia A. Silva-Pineda ${ }^{2}$, Sergio R.S. Cevallos ${ }^{2}$ \\ ${ }^{1}$ Paleoconifer Consulting Ltd., Edmonton, AB, T6X 0X7, Canada. \\ ${ }^{2}$ Departamento de Paleontología, Instituto de Geología, UNAM, Ciudad Universitaria, Del. Coyoacán, México D.F., 04510 , México. \\ *paleoconifer@gmail.com
}

\begin{abstract}
This paper describes the first Permian walchian conifer from Mexico based on several specimens preserved as compressions/ impressions. The material comes from the Tuzancoa Formation in the state of Hidalgo, Central Mexico. It is described as Calnalia hidalguensis gen. nov. et sp. nov. a new conifer morphotaxon based on isolated lateral branches with leaves. This new conifer has some of the smallest branches and leaves found among previously described walchians. Calnalia hidalguensis has two types of branches (ovoid and deltoid) with simple and helically arranged leaves. Leaves are narrowly triangular to linear in front view, slightly concave and spreading (penultimate shoots) to slightly concave to slightly S-shaped (ultimate shoots), in side view. Leaves range from $3.2 \mathrm{~mm}$ long by $0.5 \mathrm{~mm}$ wide on penultimate shoots, to $1.3-2.9 \mathrm{~mm}$ long by $0.4-0.9 \mathrm{~mm}$ wide on ultimate shoots, with angles of leaf insertion ranging from $16^{\circ}$ to $39^{\circ}$. The new species is most similar to Emporia lockardii Mapes and Rothwell, Walchia goeppertiana Florin, Walchia mucronata Florin, and Otovicia hypnoides Kerp, Poort, Swinkels \& Verwer. However, none of these have the same ranges of morphological variation found in the leaves of Mexican species. The new taxon expands the diversity of walchian conifers at the end of the Paleozoic in America, and marks the beginning of new research of Permian floras in Mexico. The presence of C. hidalguensis and other gymnosperms, to be described, reinforces the presence of an arc along the Oaxaquia block that connected Mexico to the North American craton during the late Paleozoic. These new data also allow us to test hypotheses about the origin and evolution of Paleozoic floras in Euramerica.
\end{abstract}

Keywords: conifer, Mexico, morphotaxa, Permian, Walchia.

\section{Resumen}

Este artículo describe la primera conifera pérmica "walchiana" con base en varias compresiones e impresiones fósiles de la Formación Tuzancoa en el Estado de Hidalgo, Centro de México. Se describe como Calnalia hidalguensis gen. nov. et sp. nov., un nuevo morfotaxón de coniferas basados en ramas laterales y hojas. Esta nueva conifera tiene unas de las ramas más pequeñas descritas hasta ahora para los miembros "walchianos" en el registro fósil, y cuenta con dos tipos de ramas (ovoide y deltoide), las cuales portan hojas simples con filotaxia helicoidal. Las hojas son ligeramente triangulares a lineares; lateralmente son ligeramente cóncavas a abiertas (penúltimo orden), y ligeramente cóncavas a ligeramente en forma de " $S$ " (último orden). El tamaño de las hojas de penúltimo orden es de $3.2 \mathrm{~mm}$ de largo por $0.5 \mathrm{~mm}$ de ancho y en las hojas de último orden de 1.3 - $2.9 \mathrm{~mm}$ de largo por 0.4 - $0.9 \mathrm{~mm}$ de ancho, con ángulos de inserción de las hojas de $16^{\circ}$ a $39^{\circ}$. La nueva especie posee mayor similitud con Emporia lockardii Mapes and Rothwell, Walchia goeppertiana Florin, Walchia mucronata Florin y Otovicia hypnoides Kerp, Poort, Swinkels \& Verwer. Sin embargo, ninguna de estas especies tiene los mismos rangos de variación morfológica que las hojas de la nueva especie Mexicana presentan. Este nuevo taxón aumenta la diversidad de estas coníferas conocida a finales del Paleozoico en el continente Americano. A su vez, la descripción de esta nueva especie abre la investigación paleobotánica durante el Pérmico en México, y su presencia, así como la de otras especies de plantas aún por describir, refuerzan la teoría de la existencia de un arco a lo largo del bloque Oaxaquilla que conectaba a México 
con el Cratón de Norteamérica a finales del Paleozoico. Estos datos nos ayudan a proponer hipótesis sobre el origen y evolución de las floras Paleozoicas de Euramérica.

Palabras clave: conifera, México, morfotaxa, Pérmico, Walchia.

\section{Introduction}

The earliest fossil conifer remains of Mexico have been described from early Permian sediments of the San Mateo area between the states of Hidalgo and Veracruz (Carrillo-Bravo, 1965; Silva-Pineda, 1987). This fossil material consisted of few isolated and highly fragmentary ultimate shoots of a Walchia-like plant. Additional conifer remains have been collected from Paso Hondo, Tuzancoa, and Patlanoaya Formations from Chiapas, Hidalgo, Veracruz and Puebla respectively (Carrillo-Bravo, 1965; HernándezGarcía, 1973; Moreno-Cano and Patiño-Ruiz, 1981; SilvaPineda, 1987; Silva-Pineda et al., 2000; Vachard et al., 2000; Silva-Pineda, 2003). These conifers are few in number and preserved as impressions and compressions with poor cuticles. The early Permian age (Wolfcampian-Leonardian) determinations for Mexican localities are based on key brachiopods, pelecipeds and fusulinids species (CarrilloBravo, 1965; Hernández-García, 1973; Moreno-Cano and Patiño-Ruiz, 1981; Vachard et al., 2000).

New material has been collected from Tuzancoa Fm. near Calnali river, Hidalgo (Figure 1). These fossils allow us to describe a new conifer species from the early Permian of Mexico. The material is characterized by isolated and fragmentary lateral branches with simple leaves that resemble many other walchian conifers around the world (Florin, 1938-45; Rothwell, 1982; Clement-Westerhof, 1987; Meyen, 1997; Rothwell et al., 1997; Kerp and Clement-Westerhof, 1991). Traditionally, fragmentary conifer remains were described as species belonging to form-genera (Florin, 1938-45; Mapes and Rothwell, 1991; Visscher et al., 1986), now known as morphotaxa (Greuter in McNeill et al., 2006). Paleozoic conifer morphotaxa lack familial affinities due to their incomplete nature and broad ranges of morphological and cuticular variation (Hernandez-Castillo et al., 2001; Hernandez-Castillo, 2005; Rothwell et al., 2005). Thus, prompting the use of different approaches and classifications to understand Paleozoic walchian conifers.

Three classification systems have been proposed for Paleozoic conifers (Mapes and Rothwell, 1991). The first classification was proposed by Florin $(1927,1938-45)$ and it was later improved and modified by Clement-Westerhof and colleagues (Clement-Westerhof, 1984, 1987; Visscher et al., 1986; Kerp and Clement-Westerhof, 1991). Although both classification systems are and/or have been used widely, they do not recognize nor integrate overlapping ranges of morphological and cuticular variation found among most walchians species (Hernandez-Castillo et al., 2001). A third classification does employ these broad ranges of variation for species delimitation (Mapes and Rothwell, 1991), therefore providing robust organcorrelations that allow reliable and complete conifer reconstructions (HernandezCastillo et al., 2001; Rothwell and Mapes, 2001; HernandezCastillo, 2005; Rothwell et al., 2005).

Although, this last method has proven to be most effective in reconstructing conifers as species of extinct plants, no new methods have been recently proposed for dealing with poorly preserved conifer morphotaxa. Therefore, the new Mexican material, from Calnali, offers an opportunity to reevaluate and update current approaches for describing and naming Paleozoic conifer morphotaxa. Furthermore, the discovery of walchian conifers, in central Mexico, may serve to test hypothesis on the origin and accretion of Mexican terrenes and blocks at the end of the Paleozoic, as previously discussed by other authors (OrtegaGutierrez et al., 1995; Sánchez-Zavala et al., 1999; Vachard et al., 2000; Centeno-García, 2005).

\section{Materials and methods}

The fossil material was collected $0.5 \mathrm{~km}$ from Calnali, Hidalgo, near Calnali River (Figure 1). This locality was originally described as part of the Guacamaya Formation (Carrillo-Bravo, 1965). However, Ochoa-Camarillo (1996) divides the Guacamaya Formation into the Tuzancoa and Otlamalacatla Formations. Recent work has provided evidence that Calnali Permian strata correspond to the Tuzancoa Formation (Rosales-Lagarde et al., 1997, 2002; Sour-Tovar et al., 2005). The Tuzancoa Formation is exposed in the northeast and central-east portions of Hidalgo state, Mexico $\left(20^{\circ} 55^{\prime}-20^{\circ} 35^{\prime} \mathrm{N}\right.$ and $98^{\circ} 40^{\prime}-98^{\circ} 30 \mathrm{~W}$, Figure 1). This formation is part of the Sierra Madre Oriental and belongs to the Huayacocotla Anticlinorium (RosalesLagarde et al., 1997). Tuzancoa Formation is a siliclastic sequence that switches to lava flows and andesitic and basaltic breccia, intercalating with sandstones, shales and lutites of volcanic origin (Figure 2). This formation is found between Precambrian metamorphic rocks (Huiznopala Gneiss) and discordant Mesozoic units (Sour-Tovar et al., 2005; Figure 2). The fossil material comes from a turbiditic section characterized by mid-fine grain vulcanoclastic sandstones alternating with siltstones that correspond to the upper most section described at Tuzancoa's Fm. type section (section 5 of Rosales-Lagarde, 2002).

The Wolfcampian to Leonardian age on this material is constrained by at least two invertebrate localities that 


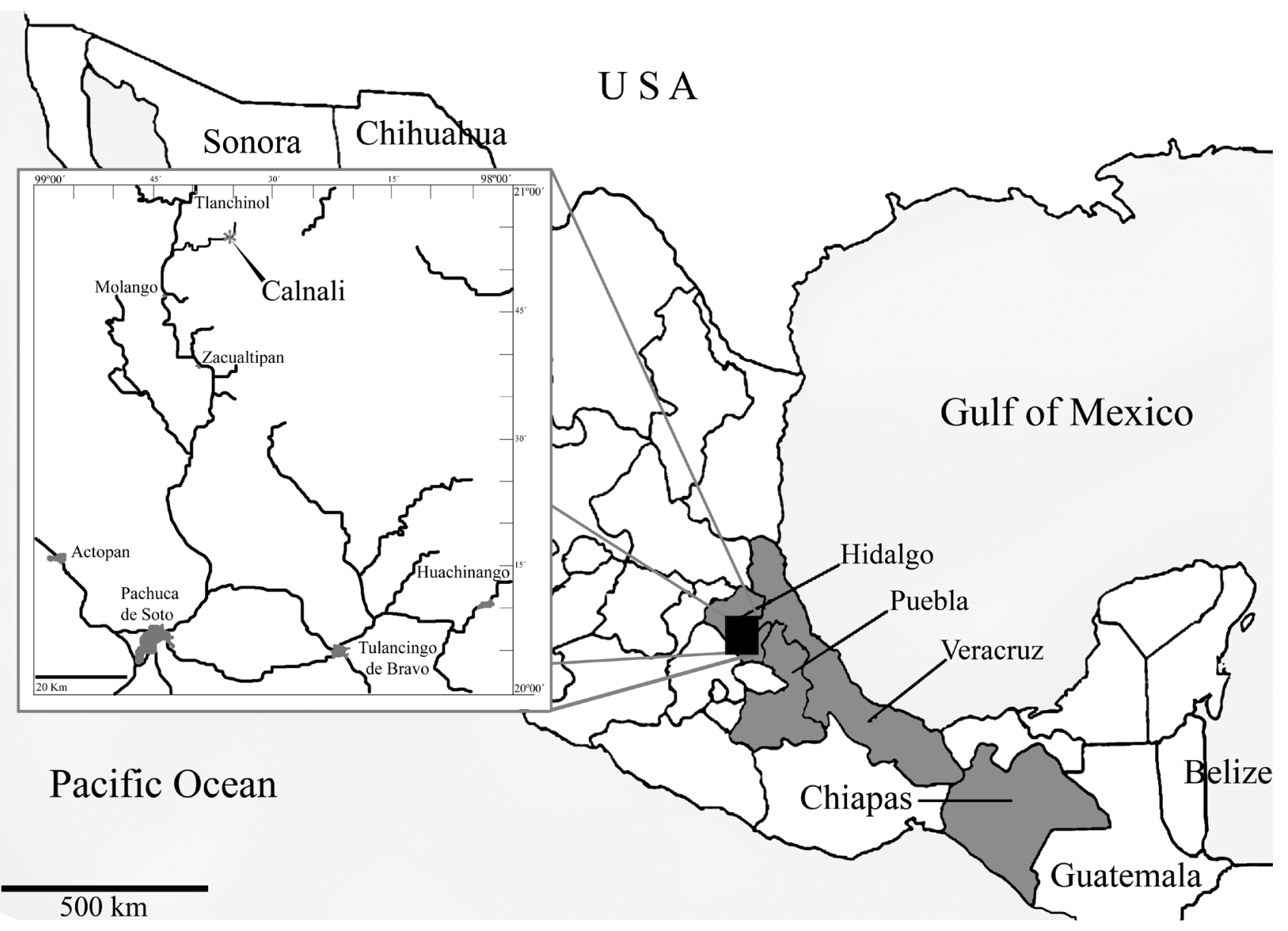

Figure 1. Map of Mexico showing states with Paleozoic conifer remains (dark) and a close up of Hidalgo state showing fossil locality (*).

are located above and below the fossil plant bearing strata (Figure 2; Carrillo-Bravo, 1965; Moreno-Cano and Patiño-Ruiz, 1981; Rosales-Lagarde, 2002; Sour-Tovar et al., 2005). This fossil conifer material is associated to fragmentary remains of Pecopteris, Neuropteris, Odontopteris, cf. Gangamopteris and Taeniopteris (SilvaPineda, 1987), and poorly preserved gigaptopterid-like? leaf remains.

The specimens are preserved as compressions/ impressions in fine to medium grain sandstones and fine-grained shales associated to large grain sandstones, limestones and tobes (Figure 2; Carrillo-Bravo, 1965; Ochoa-Camarillo, 1996; Silva-Pineda et al., 2000). Specimens were prepared using needles to remove sediments on top of branches and leaves. Light microscopy was conducted using Zeiss Stemi DV4 microscope. Images were captured with a Nikon CoolPix 4300 (Nikon Corp., Japan) and an AxioCam MRc Rev. 2/3.3V (Zeiss Inc., Germany) digital cameras. Images were processed using Adobe Photoshop CS3. Measurements of digitized specimens were taken using Image J ver. $1.36 \mathrm{~b}$ (Abramoff et al., 2004) according to Hernandez-Castillo (2005). All specimens are stored in the Colección del Laboratorio de
Paleobotanica, Instituto de Geología, Mexico City, Mexico with collection numbers IGM-PB 1254- IGM-PB 1284.

\section{Systematics}

$$
\begin{aligned}
& \text { Class - Coniferopsida } \\
& \text { Order - Voltziales } \\
& \text { Family - Unknown }
\end{aligned}
$$

Genus - Calnalia Hernandez-Castillo, Silva-Pineda et Cevallos Ferriz

Calnalia hidalguensis Hernandez-Castillo, Silva-Pineda et Cevallos Ferriz (Figs. 2-11)

Calnalia hidalguensis diagnosis - Lateral branches plagiotropic, ovoid to deltoid, 4.0 to $15 \mathrm{~cm}$ long and 4.5 to $9.4 \mathrm{~cm}$ wide; shoots of penultimate order up to $15 \mathrm{~cm}$ long, $0.4 \mathrm{~cm}$ wide; shoots of ultimate order up to $4.8 \mathrm{~cm}$ long, $0.21 \mathrm{~cm}$ wide; leaves on penultimate shoots helical, simple, narrowly triangular to linear (front view), slightly concave and spreading (side view), 2.6-3.2 mm long, 0.3-0.5 mm wide; leaves on ultimate shoots helical, simple, narrowly 
triangular to linear (front view), slightly concave to slightly S-shaped (side view), 1.3-2.9 mm long, 0.4-0.9 mm wide, angles of insertion $16^{\circ}-39^{\circ}$ (Figures 2-14).

Holotype: Penultimate shoot bearing ultimate shoots with leaves. Specimen IGM-PB 1254, Figures 2, 6.

Paratypes: Branches showing leaf morphology on penultimate and ultimate shoots, IGM-PB 1256, IGM-PB 1258 (Figures 3, 4). Leaves of penultimate shoots IGM-PB 1263, IGM-PB 1264 and IGM-PB 1254 (Figure 5, 6, 7). Leaves on ultimate shoots IGM-PB 1263 (Figures 8, 11), IGM-PB 1274 (Figure 9), IGM-PB 1279 (Figure 10).

Collecting locality: Calnali River $\left(20^{\circ} 55^{\prime}-20^{\circ} 35^{\prime} \mathrm{N}\right.$ and $98^{\circ} 40^{\prime}-98^{\circ} 30 \mathrm{~W}$ ), Municipio de Calnali, Hidalgo, Mexico. Figure 1.

Stratigraphic occurrence and age: Huayacocotla Anticlinorium, Tuzcanoa Formation, early Permian (Wolfcampian-Leonardian/Sakmarian-Artinskian), Figure 2 .

Etymology: The specific epithet hidalguensis refers to Hidalgo State in Central Mexico.

\section{Description}

The new species is represented by small lateral plagiotropic branches with a penultimate shoot bearing several ultimate shoots (Figures 2-5). Both branching orders are covered by helically arranged simple leaves (Figures 6-11). Branches range in shape from ovoid to slightly deltoid (Figures 2-5). Branches are small (up to $15 \mathrm{~cm} \mathrm{long),} \mathrm{but}$ most of them are often broken. Penultimate shoots are up to $15 \mathrm{~cm}$ and up to $4 \mathrm{~mm}$ wide. Ultimate order shoots may be straight or slightly recurved depending on branch type and size (Figures 2-5). Some branches display straight ultimate shoots with insertion angles ranging from $45^{\circ}$ to $90^{\circ}$ (Figures 2-4), while other ones have ultimate shoots that are recurved giving the branch an ovate shape (Figures 3, 5).

Shoots, of penultimate order, are covered by helically arranged, simple leaves (Figures 2, 3), which are often not well preserved. Leaves on penultimate shoots are narrowly triangular to linear in front view and slightly concave and spreading in side view (Figures 6, 7). They are narrowly

Table 1. Comparison of leaves of penultimate order shoots of Calnalia hidalguensis gen. nov. et sp. nov. and other Lebachioid Paleozoic walchian conifers.

\begin{tabular}{|c|c|c|c|c|c|c|}
\hline \multirow{2}{*}{$\begin{array}{l}\text { Species/ } \\
\text { Characters }\end{array}$} & \multicolumn{2}{|c|}{ Architecture } & \multicolumn{4}{|c|}{ Leaves of penultimate order } \\
\hline & Stem & $\begin{array}{c}\text { Lateral } \\
\text { branches }\end{array}$ & $\begin{array}{l}\text { Length } \\
\text { (mm) }\end{array}$ & $\begin{array}{l}\text { Width } \\
(\mathrm{mm})\end{array}$ & $\begin{array}{c}\text { Shape } \\
\text { (face view) }\end{array}$ & $\begin{array}{c}\text { Shape } \\
\text { (side view) }\end{array}$ \\
\hline Calnalia hidalguensis & $?$ & Plagiotropic & 3.2 & 0.5 & $\mathrm{Nt}, \mathrm{Li}$ & $\mathrm{Sc}, \mathrm{Sp}$ \\
\hline${ }^{1}$ Emporia lockardii $*$ & Orthotropic? & Plagiotropic & $5.0-10.0$ & $1.0-2.1$ & Nt, Li, Fr & $S c, S s s$ \\
\hline${ }^{2}$ Emporia cryptica & Orthotropic & Plagiotropic & $2.4-7.1$ & $0.6-2.0$ & $\mathrm{Nt}, \mathrm{Li}$ & Ss, $\mathbf{S p}$ \\
\hline${ }^{2}$ Emporia royalii $* *$ & Orthotropic? & Plagiotropic & $1.6-5.0$ & $0.3 .-1.5$ & Nt, Li, Fr & Ss, Sss \\
\hline${ }^{3}$ Lebachia americana & $?$ & Plagiotropic & $3.5-7$ & $1-1.5$ & St, Sl & $S c, S p, S s s$ \\
\hline${ }^{3}$ Lebachia angustifolia & $?$ & Plagiotropic & $4-15$ & 01-feb & $N t, S t, S l$ & $\mathrm{Sc}, \mathrm{Sp}$ \\
\hline${ }^{4}$ Lebachia garnettensis & $?$ & Plagiotropic & $3.0-16.0$ & $1.5-2.5$ & $\mathrm{Nt}, \mathrm{Li}$ & $S c$ \\
\hline${ }^{5}$ Lebachia goeppertiana & $?$ & Plagiotropic & $2-4.7$ & $0.3-0.8$ & $N t, L i, S l$ & $\mathrm{Sc}, \mathrm{Sp}$ \\
\hline${ }^{5}$ Lebachia mucronata & $?$ & Plagiotropic & $3-8$ & 01-feb & Sl, St & $\mathrm{Sc}, \mathrm{Sp}$ \\
\hline${ }^{5}$ Lebachia parvifolia & $?$ & Plagiotropic & $4-15$ & 01-feb & $N t, S t, L i$ & $S c, L i, S l p$ \\
\hline${ }^{5}$ Lebachia piniformis var solmsii & $?$ & Plagiotropic & $6.5-10.5$ & $1.4-2.9$ & $\mathrm{Nt}, \mathrm{Li}$ & $\mathrm{Sc}, \mathrm{Sp}$ \\
\hline${ }^{6}$ Otovicia hypnoides $*$ & $?$ & Plagiotropic & $2.0-8.0$ & $1.0-1.5$ & St, La, Fr & Sc, Ss \\
\hline${ }^{7}$ Thucydia mahoningensis & Orthotropic & Plagiotropic & $5-12.5$ & $1.0-1.5$ & $\mathrm{Nt}, \mathrm{Li}$ & $S c, S s$ \\
\hline${ }^{8}$ Utrechtia floriniformis * & Orthotropic? & Plagiotropic & $12-25$ & $1.5-3.0$ & $\mathbf{N t}, \mathbf{L i}, \mathbf{F r}$ & Sc \\
\hline
\end{tabular}

Character combinations that differ from those of $C$. hidalguensis are recorded in bold face type and overlapping characters are recorded in italics. * Heterophylly present (forked leaves). Modified from Hernandez-Castillo et al., 2001. ${ }^{1}$ Hernandez-Castillo, 2005; Mapes and Rothwell, $1984,1991$. ${ }^{2}$ Hernandez-Castillo, 2005. ${ }^{3}$ Florin 1938-45. ${ }^{4}$ Emended by Winston (1984). ${ }^{5}$ Florin 1938-45. ${ }^{6}$ Kerp et al., 1990; Florin (1938-45). ${ }^{7}$ Hernandez-Castillo et al. , 2001. ${ }^{8}$ Florin 1938-45; Mapes and Rothwell, 1991. Leaf shape abbreviations: Li $=$ Linear, Nt $=$ Narrowly triangular, $\mathrm{Sc}=\mathrm{Slightly}$ concave, S1 $=$ Slightly lanceolate, $\mathrm{Sp}=$ Spreading (extending nearly to the horizontal), $\mathrm{Slp}=$ Slightly spreading (not necessarily extending nearly to the horizontal plane), $\mathrm{Ss}=\mathrm{S}$-shaped, $\mathrm{Sss}=$ Slightly S-shaped, $\mathrm{St}=$ Sub-triangular. 


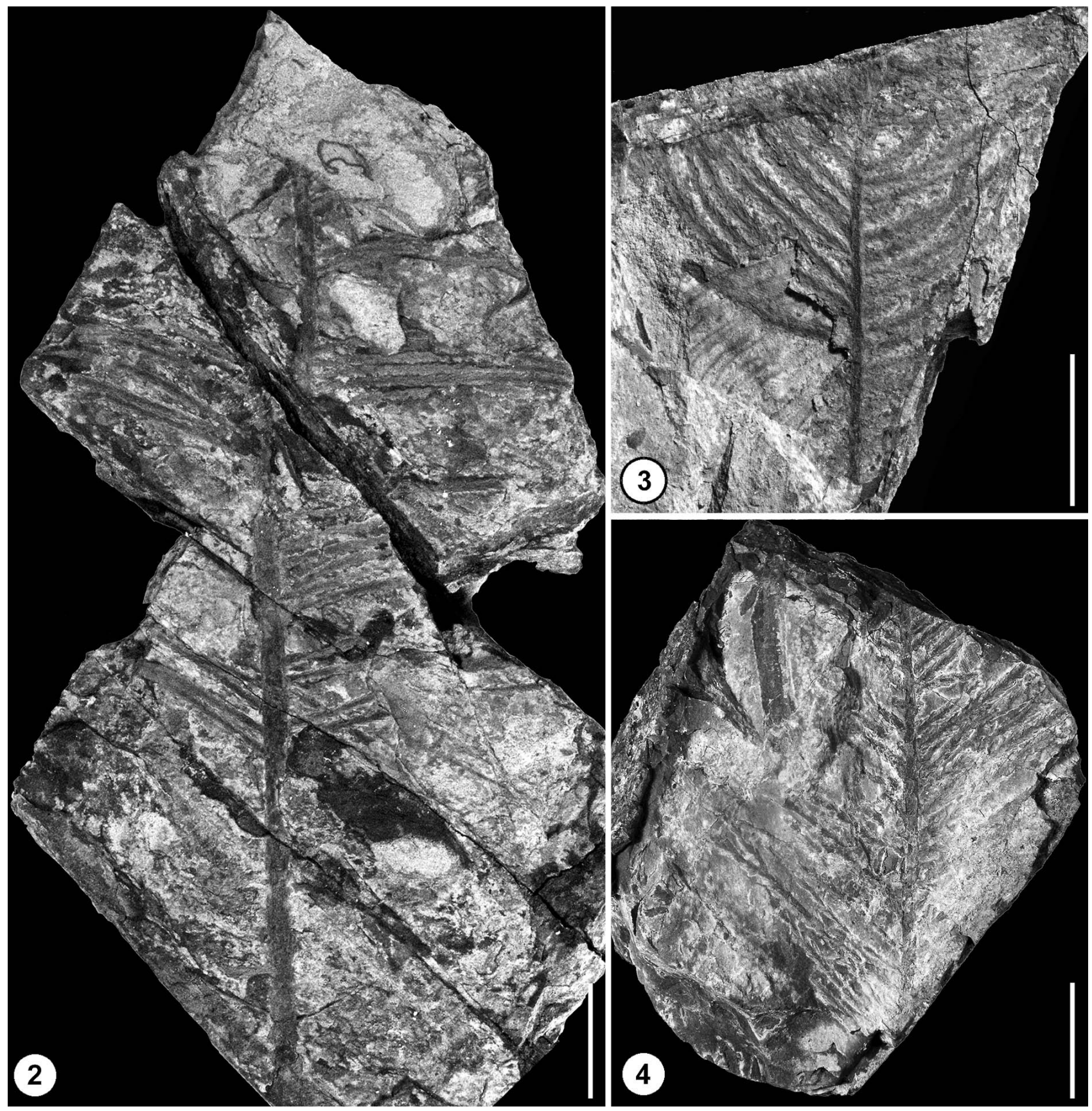

Figures 2-4. Calnalia hidalguensis gen. nov.et sp. nov. variation of plagiotropic lateral branches. 2. Lateral branch showing stem of penultimate order and attached shoots of ultimate order. IGM-PB 1254 , scale $b a r=2 \mathrm{~cm}$. 3. Lateral branch showing several ultimate shoots. Note shoot curvature towards the branch apex. IGM-PB 1256, scale bar $=2 \mathrm{~cm}$. 4. Lateral branch showing penultimate and ultimate shoots. Note the angles of insertion of ultimate order shoots. IGM-PB 1258, scale bar $=2 \mathrm{~cm}$.

triangular to linear in front view and slightly concave to spreading in side view. Leaves range from 2.6 to $3.2 \mathrm{~mm}$ in length and 0.3 to $0.5 \mathrm{~mm}$ in width. Leaves have angles of insertion close to 90 (Figures 6, 7). However, more leaves are needed to assess the full range of morphological variation of this leaf order.

Shoots of ultimate order are found attached to penultimate shoots in lateral branches, or isolated and often fragmentary (Figures 2-4; Figures 9, 10). Simple and helically arranged leaves cover these shoots. Leaves range from 1.3 to $2.9 \mathrm{~mm}$ in length and 0.4 to $0.9 \mathrm{~mm}$ in width. They are narrowly triangular to linear in front view, and slightly S-shaped to slightly concave in side view (Figures 8-11). They can be adpressed with angles of insertion ranging from $16^{\circ}$ to $24^{\circ}$ (Figures 8,11 ) to slightly adpressed with angles ranging from $25^{\circ}$ to $39^{\circ}$ (Figures 9, 10). Although leaves on ultimate shoots may be slightly to fully adpressed, their angles of insertion at the base and apex of the ultimate shoot are rather 


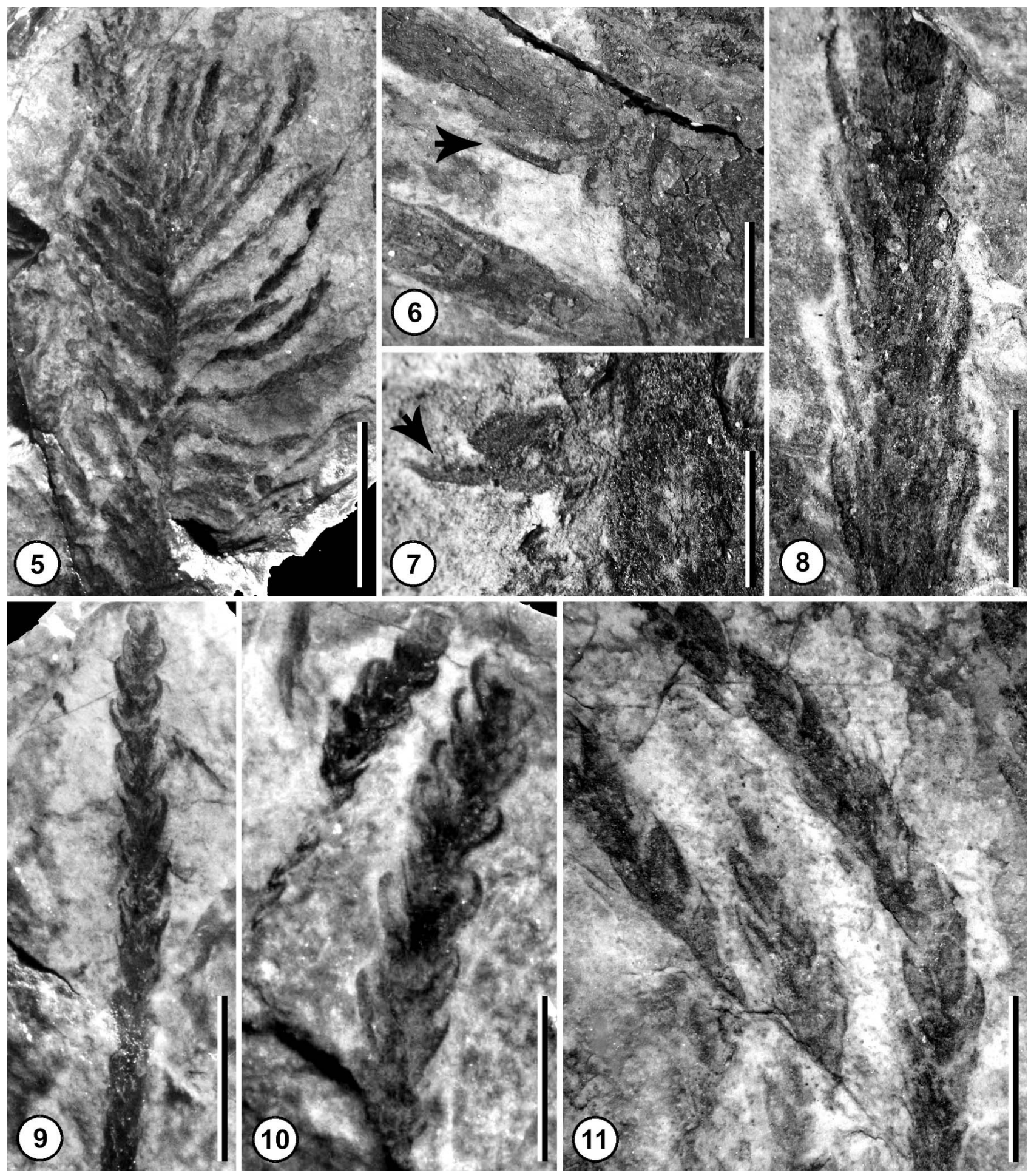

Figures 5-11. Calnalia hidalguensis gen. nov.et sp. nov. lateral branch and leaf variation on shoots of ultimate order. Note the angles of insertion of leaves, see text for explanation. 5. Ovate plagiotropic lateral branch showing branch apex. IGM-PB 1263, scale bar $=3 \mathrm{~mm}$. 6 . Penultimate shoot showing attached leaf. Note that the leaf is located below a shoot of ultimate order (arrow). IGM-PB 1264, scale bar $=2 \mathrm{~mm}$. 7. Penultimate shoot showing attached slightly spreading leaf. IGM-PB 1254, scale bar $=2 \mathrm{~mm}$. 8. Shoot showing adpressed, slightly concave leaves. IGM-PB 1263, scale bar $=2 \mathrm{~mm}$. 9. Shoot showing non-adpressed and slightly concave leaves. IGM-PB 1274 , scale bar $=2 \mathrm{~mm}$. 10. Shoot showing non-adpressed, slightly concave to slightly S-shaped leaves. IGM-PB 1279, scale bar $=2 \mathrm{~mm}$. 11. Shoot showing adpressed, slightly concave leaves. Note the leaf thickness. IGM-PB 1263 , scale bar $=2 \mathrm{~mm}$. 
similar. Leaf shape (in side view) and angles of insertion depend on the branch type, position within the branch, and overall preservation (Figures 8-11). No heterophylly has been observed between the leaves on penultimate and ultimate shoots so far.

\section{Disscusion}

5.1. Calnalia hidalguensis and its relationship to Paleozoic walchian conifers

Calnalia hidalguensis is described as a new morphotaxon for vegetative lateral plagiotropic branches of Paleozoic conifers, with simple, helically arranged leaves and no cuticles preserved. Lateral branches of C. hidalguensis conform to the traditional walchian conifer morphology (Florin, 1938-45). Walchian conifers are common gymnosperms from Upper Paleozoic sediments of Euramerica (Florin, 1938-45; Rothwell, 1982; ClementWesterhof, 1984). These conifers typically display lateral plagiotropic branches composed of a penultimate shoot that bears several ultimate shoots similar to those of C. hidalguensis. This new taxon is similar to commonly known Euramerican Paleozoic conifers previously described by Florin (1938-45), Winston (1984), Kerp et al. (1990), Mapes and Rothwell (1991), Hernandez-Castillo et al. (2001), and Hernandez-Castillo (2005).

Calnalia hidalguensis have simple leaves on penultimate shoots that contrast with taxa bearing forked penultimate leaves (Table 2). The presence or absence of simple or forked leaves on penultimate shoots is used to distinguish taxa and heterophylly in conifers (Hernandez-Castillo et al., 2001). This is important because some of these conifers display different types of heterophylly, suggesting different tree architectural types, similar to those found in living conifers (Rothwell and Mapes, 2001; Hernandez-Castillo et al., 2003; Hernandez-Castillo, 2005). Plagiotropic branches of

Table 2. Comparison of leaves of ultimate order shoots of Calnalia hidalguensis gen. nov. et sp. nov. and other Lebachioid Paleozoic walchian conifers.

\section{Species/}

Characters

\section{Leaves of ultimate order}

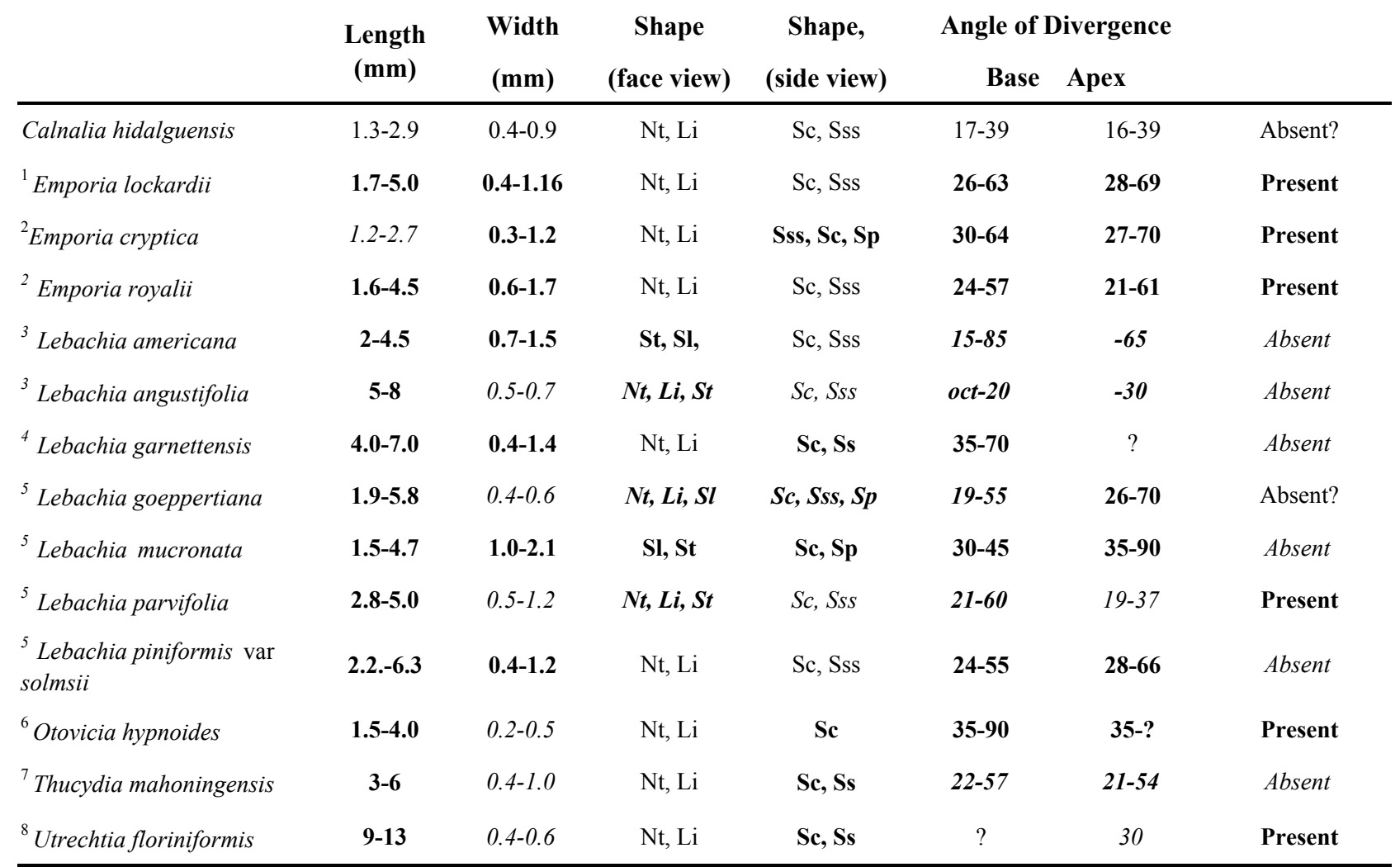

Character combinations that differ from those of $C$. hidalguensis are recorded in bold face type and overlapping characters are recorded in italics. Modified from Hernandez-Castillo et al., 2001. ${ }^{1}$ Hernandez-Castillo, 2005; Mapes and Rothwell, 1984, 1991. ${ }^{2}$ Hernandez-Castillo, 2005. ${ }^{3}$ Florin $1938-45 .{ }^{4}$ Emended by Winston (1984). ${ }^{5}$ Florin 1938-45. ${ }^{6}$ Kerp et al., 1990; Florin (1938-45). ${ }^{7}$ Hernandez-Castillo et al., 2001. ${ }^{8}$ Florin 1938-45; Mapes and Rothwell, 1991. Leaf shape abbreviations: $\mathrm{Li}=$ Linear, $\mathrm{Nt}=$ Narrowly triangular, $\mathrm{Sc}=$ Slightly concave, $\mathrm{Sl}=$ Slightly lanceolate, $\mathrm{Sp}=\mathrm{Spreading}(\mathrm{extending}$ nearly to the horizontal), Slp = Slightly spreading (not necessarily extending nearly to the horizontal plane), Ss = S-shaped, Sss = Slightly S-shaped, St= Subtriangular. * Heterophylly is based on differences in the shape of leaves, where two distinctive types of leaves are known (Hernandez-Castillo et al., 2001). 
C. hidalguensis display penultimate order shoots bearing leaves that are most similar to those of Lebachia piniformis var. solmsii Florin (Table 2). Unfortunately, not many penultimate order leaves have been found, which prevents us from more comprehensive comparisons to the very few walchian species with well-preserved penultimate leaves.

Shoots, of ultimate order, bear some of the smallest leaves found among walchian conifers of Europe and North America (Table 3). Leaves range from 1.3 to $3.2 \mathrm{~mm}$ long and fall within the ranges of variation of species such as Emporia lockardii (Mapes \& Rothwell) Mapes \& Rothwell, two new Emporia species, Emporia cryptica and Emporia royalii, from the Hamilton Quarry (Hernandez-Castillo et al., 2009b, 2009c), Lebachia goeppertiana Florin, Lebachia mucronata Florin, and Otovicia hypnoides Kerp, Poort Swinkels \& Werver (Table 3). In contrast, other euramerican conifers, such as Lebachia americana Florin, Lebachia angustifolia Florin, Lebachia garnettensis (Florin) Winston, Thucydia mahoningensis Hernandez-Castillo, Rothwell and Mapes, and Utrechtia floriniformis Mapes and Rothwell, display larger leaves than those of Calnalia (Table $3)$. Angles of insertion of leaves, in most euramerican taxa, either overlap or are greater than those of Calnalia (Table 3). Therefore, no other previously described walchian conifer morphotaxa have leaves with same ranges of variation as those recorded for Calnalia hidalguensis.

\subsection{Conifer morphotaxa}

Traditionally, Paleozoic conifer remains based on isolated lateral branches, shoots with leaves, and cones have been described as form-genera and now designated as morphotaxa (Stewart and Rothwell, 1993; Greuter et al., 2000; McNeill et al., 2006; Table 1). According to the ICBN (Vienna Code), "a morphotaxon is defined as a fossil taxon which, for nomenclatural purposes, comprises only the one part, life-history stage, or preservational state represented by the corresponding nomenclatural type" (McNeill et al., 2006). Therefore, the new Mexican conifer conforms to the concept of a new morphotaxon for walchian conifers represented by two orders of lateral branches with attached leaves.

Most Paleozoic conifer morphotaxa lack familial affinities due to broad and/or overlapping ranges of morphological and cuticular variation of leaves and leaf-like structures such as, pollen cone microsporophylls, ovulate cone bracts and sterile scales (Hernandez-Castillo et al., 2001; 2009b). Species identification, including familial affinities among these conifers, are controversial due to these overlapping ranges of variation and the absence of organic connections (Hernandez-Castillo et al., 2001; Rothwell et al., 2005; Hernandez-Castillo, 2005). The lack of unequivocal sets of diagnostic characters, used to characterize and distinguish walchian conifer species, has prompted different approaches to solving Paleozoic conifer systematics. Hence, each approach creates different classifications with alternative morphotaxa (Table 1; Visscher et al., 1986; Mapes and Rothwell, 1991).

Traditional approaches allow workers to describe conifer remains based on conventional morphological and/ or cuticular characters (Florin, 1927, 1938-45; ClementWesterhof, 1984, 1987, 1988; Visscher et al., 1986; Kerp et al., 1990). However, these approaches fail to acknowledge and deal with known broad ranges of variation within and among walchian conifer species (Hernandez-Castillo et al., 2001; Hernandez-Castillo, 2005). A third approach proposed by Mapes and collaborators allows us to accurately correlate different conifer organs in order to reconstruct new conifer plants and survey known ranges of variation (Rothwell and Mapes, 2001; Hernandez-Castillo et al., 2001; Hernandez-Castillo et al., 2003). Nevertheless, this approach requires of dozens or hundreds of conifer remains.

Due to the small amount of fossil conifer specimens and poor preservation (no cuticles), we decided to use a combination of techniques from previous approaches, where few specimens are described using conventional morphological characters (i.e., Florin and ClementWesterhof) and their ranges of variation (HernandezCastillo, 2005), by surveying fourteen morphological characters of branches and leaves and comparing them to previously described species (Hernandez-Castillo and Silva-Pineda, 2009). This will permit employing a combination of approaches and preparing our material for future comparisons with the best-known and reconstructed walchian conifers from Euramerica.

Calnalia hidalguensis lateral branches and leaves are some of the smallest ever found among walchian conifers (Table 1). Comparisons to previous taxa suggest than both shape and size of Calnalia branches relate to apical and medium-size branches of young or juvenile walchian and araucarian trees (Hernandez-Castillo et al., 2003, 2008, 2009). This assumption is supported by the lack of a) fully developed oblong-shaped lateral branches (basal and/or mature branches); b) narrowly oblong-shaped branches (most apical branches), and c) reproductive structures, as seen in most previously described morphotaxa and newly reconstructed Paleozoic conifers (Florin, 1938-45; ClementWesterhof, 1994; Mapes and Rothwell,1991; HernandezCastillo et al., 2003, 2008, 2009a, 2009c; Looy, 2007).

Calnalia is here represented by a small sample of young branches and leaves with unique ranges of morphological variation that do not correspond to any known walchian conifer, and as such deserves to be placed in its own genus and species. The use of previously assigned morphotaxa names is not recommended for newly discovered species with distinct ranges of morphological variation if 1) the taxon is undoubtedly correlated to unknown and/ or overlapping ranges of morphological variation (e.g., Walchia); and 2) if the taxon is in conflict with current classifications (Visscher, et al., 1986; Mapes and Rothwell, 1991; Hernandez-Castillo et al., 2001). This approach prevents us from using ambiguous morphotaxa names that 
Early Permian conifer remains from Central Mexico and reevaluation of Paleozoic conifer morphotaxa

Table 3. Current conifer classification approaches used to describe early conifers and recognized morphotaxa.

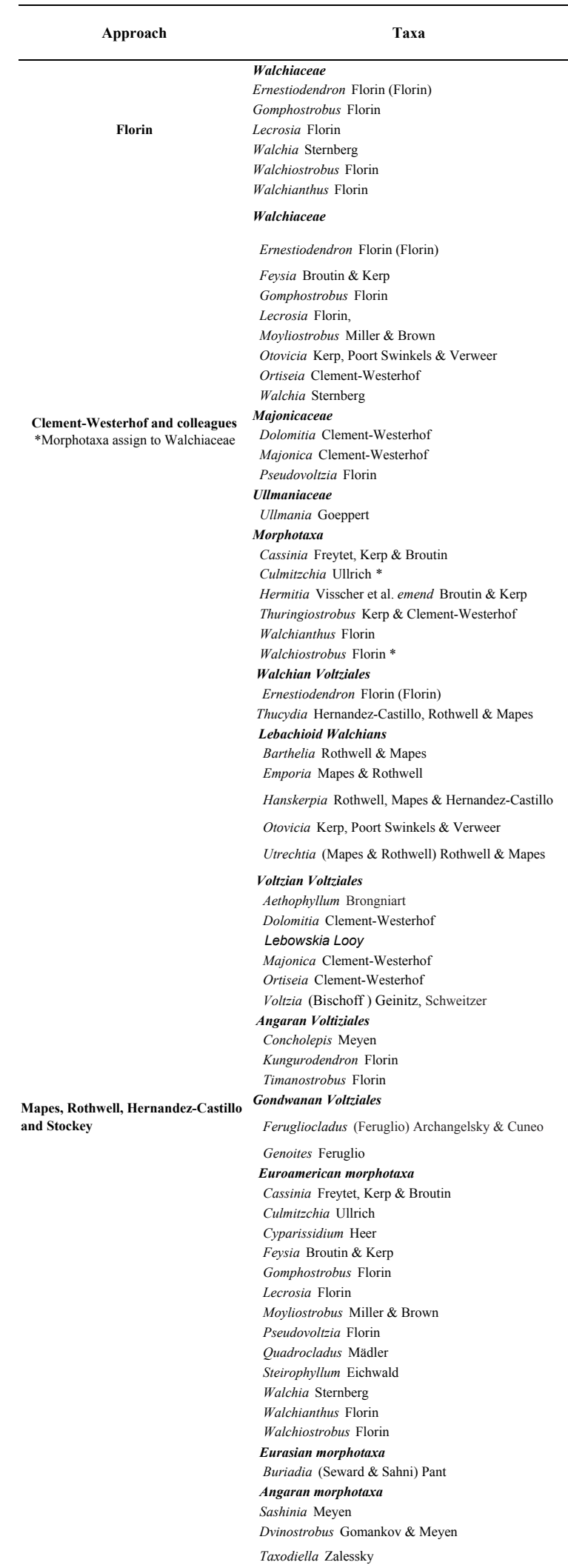

Walchian, Lebachioid, Voltzian, Gondwanan and Angaran Voltiziales are clades names derived from phylogenetic analyses (Rothwell et al., 2005). Generic names from: Seward and Sahni, (1920), Florin (1927, 1938-45), Schweitzer (1963, 1996), Pant (1982), Clement-Westerhof (1984, 1987), Winston (1984), Visscher et al. (1986), Archangelsky and Cuneo (1987), Meyen (1987, 1997), Kerp and Clement-Westerhof (1991, 1996), Mapes and Rothwell (1991), Freytet et al. (1996) Kerp et al. (1996), Hernandez-Castillo et al. (2001; 2009a-c), Rothwell and Mapes (2001), Rothwell and Mapes (2001, 2003), Hernandez-Castillo (2005), Looy 2007. 
would lead to more confusing walchian conifer species concepts.

\subsection{Permian outcrops and conifers of Mexico.}

Walchia hidalguensis is the first species of conifer fossils to be described from the Permian of Mexico and its general features resemble most closely Euramerican Lebachioid conifers. In addition, Walchia expands the present distribution for walchian conifers in North America. Typical Lebachioid conifers (Rothwell et al., 2005) have been described and reconstructed from the Upper Carboniferous to the Late Permian of Europe and North America. However, additional records have been found in North Africa and the Middle East (El Wartiti et al., 1986; Broutin et al., 1986, 1998; Berthelin et al., 2003), and new sites in Texas (USA) and Blanzy (France) (Bercovici and Broutin, 2007; Looy, 2007), therefore expanding the geographic distribution of Lebachioid walchians at the end of the Paleozoic (Florin, 1938-45; Rothwell, 1982; Mapes and Rothwell, 1984; Rothwell et al., 1997).

Walchian fossils have been collected from sediments that currently are located in central Mexico, but this region was once part of the southern most region of the Sierra Madre terrane (Rosales-Lagarde, 2002; Centeno-García, 2005). The Sierra Madre terrane was part of the Oaxaquia block along with Coahuila terrane. It is believed that the Oaxaquia block was part of Gondwana until it collided with North America at the Carboniferous-Permian boundary (Pindell, 1985; Centeno-García, 2004, 2005). Different models are now trying to explain this accretion process and posterior formation of the Mexican paleogeographic regions (Pindell, 1985; Ortega-Gutierrez et al., 1995; Dickinson and Lawton, 2001). One of the models with the strongest evidence (Pindell's model) relies on strong faunal associations during the Mississippian among the Coahuila and Sierra Madre terranes, and the mid-continent province in North America (Stewart et al., 1999; Navarro-Santillán et al., 2002; Centeno-García, 2005), suggesting that these terranes were part of the North American Craton at the end of the Paleozoic. The presence of Calnalia and other taxa yet to be described in the Sierra Madre terrane reinforces this model. Preliminary surveys of at least six localities in the Tuzancoa Formation suggest similarities with Permian floras of Texas (DiMichele et al., 2000, 2001). Furthermore, walchian conifer remains found in Texas resemble typical Lebachioid conifers and Walchian Voltziales (DiMichele et al., 2000, 2001; Looy, 2007, 2007a). Some of these Texan conifers resemble branches/leaves of Calnalia, while others resemble typical branches/leaves and cones of Upper Permian Majonicaceae conifers (Looy, 2007). These facts add more evidence of the presence of an arc found along the Coahuila and Sierra Madre terranes (Oaxaquia block) that connected Texas to these Mexican terranes by the early Permian (Centeno-García, 2005).
Calnalia is the first species to be described from a series of new localities in the early Permian of Mexico. Together with several localities in the states of Chihuahua, Chiapas, Coahuila, Guerrero, Puebla, Sonora and Veracruz, conform an ample suite of early Permian outcrops throughout Mexico. Many of these localities yield conifer remains that conform to typical walchians, thus increasing the paleo-distribution of these conifers during the early Permian. Thus far, most localities with plants seem to be correlated to localities with fusulinids in the North, Central and South regions of Mexico (Vachard et al., 2000), adding another component to the depositional and taphonomic processes regarding walchian conifers in Mexico. This presents the urgent need of producing more multi-disciplinary research to assess and correlate late Permian localities in Mexico. Furthermore, geological, geochemical, paleontological, sedimentological, and stratigraphical data needs to be gathered, organized and compared to previous hypotheses that could explain the origin and evolution of blocks, terranes, faunas, and floras in Mexico. Calnalia hidalguensis represents the first step in this direction and the beginning of new paleobotanical research into the Paleozoic of Mexico.

\section{Acknowledgement}

We thank Hector Ochoa-Camarillo (1996), Blanca Buitrón and Carlos Castañeda-Posadas for their help in collecting some of the material, and Laura CalvilloCanadell, Sergio R. S. Cevallos-Ferriz and Gar W. Rothwell for their helpful comments of this manuscript. This research was supported in part by DGAPA and CONACyT (Postdoctoral Grants 051006 and 050213) and CONACyT research grant 054521 to GRHC.

\section{References}

Abramoff, M.D., Magelhaes, P.J., Ram, S.J., 2004, Image Processing with Image: Journal of Biophotography International, 11, 36-42.

Bercovici A., Broutin J., 2007, The Autunian flora of the Martinet site (Blanzy-Montceau les Mines, Burgundy, France): Description, Taphonomic study and Palaeoenvironmental implications: Séminaire International d Paleobotanique Evolution des Plantes Progr Abst, $45 \mathrm{p}$.

Berthelin, M., Broutin, J., Kerp, H., Crasquin-Soleau, S., Platel, J.P., Roger, J., 2003, The Oman Gharif mixed paleoflora; a useful tool for testing Permian Pangea reconstructions: Palaeogeography, Palaeoclimatology, Palaeoecology, 196, 85-98.

Broutin, J., El Wartiti, M., Freytet, P., Heyler, D., Larhrib, M., Morel, J.L., 1986, Nouvelles découvertes paléontologiques dans les bassin détritique carbonaté permien de Tiddas (Maroc Central): Comptes Rendus de l'Académie des Sciences Paris, Série II, 305, 143-148.

Broutin, J., Assoumi, H., El Wartiti, M., Freytet, P., Kerp, H., Quesada, C., Toutin-Morin, T., 1998, The Permian basins of Tiddas, BouAcouch and Khenifra (central Morocco). Biostratigraphic and palaeophytogeographic implications, in Crasquin-Soleau, S., Barrier, É. (Eds.), Peri-Tethys Memoir 4: epicratonic basins of Peri -Tethyan platforms: Mémoires du Muséum National d'Histoire Naturelle, 179, 257-278. 
Carrillo-Bravo, J., 1965, Estudio geológico de una parte del Anticlinorio de Huayacocotla: Boletín de la Asociación Mexicana de Geólogos Petroleros, 27, 73-96.

Centeno-García, E., 2004, Configuración geológica del estado, in García-Mendoza, A.J., Ordoñez, M.J., Briones-Salas, M. (Eds.), Biodiversidad de Oaxaca. Instituto de Biología, UNAM-Fondo Oaxaqueño para la conservación de la naturaleza-World Wildlife Fund Mexico, 29-42.

Centeno-García, E., 2005, Review of Upper Paleozoic and Lower Mesozoic stratigraphy and depositional environments of central and west Mexico: Constraints on terrene analysis and paleogeography, in Anderson, T.H., Nourse, J.A., Mckee, J.W., Steiner, M.B. (Eds.), The Mojave-Sonora megasear hypothesis: Development, assessment and alternatives: Geological Society of America Special Papers, 393, 233-258.

Clement-Westerhof, J.A., 1984, Aspects of Permian palaeobotany and palynology; IV, The conifer OrtiseiaFlorin from the Val Gardena Formation of the Dolomites and the Vicentinian Alps (Italy) with special reference to a revised concept of the Walchiaceae (Goeppert) Schimper: Review of Palaeobotany and Palynology, 41, 51-166.

Clement-Westerhof, J.A., 1987, Aspects of Permian palaeobotany and palynology; VII, The Majonicaceae, a new family of Late Permian conifers: Review of Palaeobotany and Palynology, 52, 375-402.

Clement-Westerhof, J.A., 1988, Morphology and phylogeny of Paleozoic conifers, in Beck, C.B., (ed.), Origin and evolution of gymnosperms: Columbia University Press, New York, 298-337.

Dickinson, W.R., Lawton, T.F., 2001, Carboniferous to Cretaceous assembly and fragmentation of Mexico: Geolgical Society of America Bulletin, 113, 1142-1160.

DiMichele, W.A., Chaney, D.S., Dixon, W.H., Nelson, W.J., Hook, R.W., 2000, An Early Permian Coastal flora from the Central Basin Platform of Gaines County, West Texas: Palaios, 15, 524-534.

DiMichele, W.A., Mamay, S.H., Chaney, D.S., Hook, R.W., Nelson, J.W., 2001, An Early Permian Flora with Late Permian and Mesozoic Affinities from North-Central Texas: Journal of Paleontology, 75, 449-460.

DiMichele, W.A., Chaney, D.S., Nelson, W.J., Lucas, S.G., Looy, C.V., Quick, K., Jun, W., 2007. A low diversity, seasonal tropical landscape dominated by conifers and peltasperms: Early Permian Abo Formation, New Mexico, Review of Paleobotany and Palynology, 145:249-273

E1 Wartiti, M, Broutin, J., Freytet, P., 1986, Premières découvertes paléontologiques dans les séries rouges carbonatées permiennes du basin de Tiddas (Maroc Central): Comptes Rendus de l'Académie des SciencesParis, Série II, 303, 263-268.

Florin, R., 1927, Preliminary descriptions of some Palaeozoic conifers: Arkiv för Botanik, 21, 1-7.

Florin, R., 1938-45, Die Koniferen des Oberkarbons und des unteren Perms: Palaeontographica Abteilung B, 85, 1-729.

Freytet, P., Kerp, H., Broutin, J., 1996, Permian freshwater stromatolites associated with the conifer shoots Cassinisia orobica Kerp et al.; a very peculiar type of fossilization: Review of Palaeobotany and Palynology, 91, 85-105.

Hernandez-Castillo, G.R., 2005, Systematics of the most ancient conifers: University of Alberta, Alberta, Canada, Ph. D., thesis, 323 p.

Hernandez-Castillo, G.R., Silva-Pineda, A., 2009, Walchian conifer remains from the early Permian of Mexico: Botanical Society of America Abstracts, $131 \mathrm{p}$.

Hernandez-Castillo G.R., Rothwell, G.W., Mapes, G., 2001, Thucydiaceae fam. nov., with a review and reevaluation of Paleozoic walchian conifers: International Journal of Plant Sciences, 162, 1155-1185.

Hernandez-Castillo, G.R., Rothwell, G.W., Stockey, R.A., Mapes, G., 2003, Growth architecture of Thucydia mahoningensis, a model for primitive walchian conifer plants: International Journal of Plant Sciences, 164, 443-452.

Hernandez-Castillo, G.R., Rothwell, G.W., Stockey, R.A., Mapes, G., 2009a, Reconstructing Emporia lockardii (Emporiaceae) Voltziales, and initial thoughts on Paleozoic conifer ecology: International Journal of Plant Sciences, 170, 1056-1074.
Hernandez-Castillo, G.R., Rothwell, G.W., Stockey, R.A., Mapes, G., 2009b, Reconstruction of the Pennsylvanian-age walchian conifer Emporia cryptica sp. nov. (Emporiaceae: Voltziales): Review of Palaeobotany and Playnology, 157, 218-237.

Hernandez-Castillo G.R., Rothwell, G.W., Stockey, R.A., Mapes, G., 2009c, A new voltzialean conifer Emporia royalii (Emporiaceae) from the Hamilton Quarry, Kansas: International Journal of Plant Sciences, 170, 1201-1227.

Hernandez-Castillo, G.R., Silva-Pineda, A., 2009, Walchian conifer remains from the early Permian of Mexico: Botanical Society of America Abstracts, 131.

Hernandez-García, R., 1973, Paleogeografía del Paleozoico de Chiapas, México: Boletin de la Asociación Mexicana de Geólogos Petroleros, 25, 79-134.

Kerp, J.H.F., Poort, R.J., Swinkels, H.A.J.M., Verwer, R., 1990, Aspects of Permian Palaeobotany and Palynology. IX. Conifer-dominated Rotliegend floras from the Saar--Nahe Basin (?Late Carboniferous-Early Permian; SW-Germany) with special reference to the reproductive biology of early conifers: Review of Palaeobotany and Palynology, 62, 205-248.

Kerp, J.H.F., Clement-Westerhof, J.A., 1991, Aspects of Permian paleobotany and palynology XII. The form-genus Walchiostrobus Florin reconsidered: Neues Jahrbuch für Geologie und Paläontologie Abhandlungen, 183, 257-268.

Kerp H., Penati, F., Brambilla, G., Clement-Westerhof, J.A, van Bergen, P.F., 1996, Aspects of Permian palaeobotany and palynology. XVI. Three-dimensionally preserved stromatolite-incrusted conifers from the Permian of the western Orobic Alps (northern Italy): Review of Palaeobotany and Palynology, 91, 63-84.

Looy, C., 2007, Extending the range of derived late Paleozoic conifers: Lebowskia gen. nov. (Majonicaceae): International Journal of Plant Sciences, 168, 957-972.

Looy, C., 2007a, The evolution of late Paleozoic conifers. Séminaire International, Paleobotany and the evolution of plants: current issues, Progr Abst, $27 \mathrm{p}$.

Mapes, G, Rothwell, G.W., 1984, Permineralized ovulate cones of Lebachia from late Palaeozoic limestones of Kansas: Palaeontology, 27, 69-94.

Mapes, G., Rothwell, G.W., 1991, Structure and relationships of primitive conifers: Neues Jahrbuch für Geologie und Paläontologie Abhandlungen, 183, 269-287.

McNeill, J., Barrie, F.R., Burdet, H.M., Demoulin, V., Hawksworth, D.L., Marhold, K., Nicolson, D.H., Prado, J., Silva, P.C., Skog, J.E., Wiersema, J.H., Turland, N.J., 2006, International Code of Botanical Nomenclature (Vienna Code) Adopted by the Seventeenth International Botanical Congress Vienna, Austria, July 2005: Gantner Verlag, Ruggell, Liechtenstein, Regnum Vegetabile, 146, 1-20.

Meyen, S. V., 1997, Permian conifers of Western Angaland: Review Palaeobotany and Palynology, 96, 351-447.

Moreno-Cano, L, Patiño-Ruiz, J., 1981, Estudio del Paleozoico en la región de Calnali, Hgo. (En la Sierra Madre Oriental): Instituto Politécnico Nacional, Escuela Superior de Ingeniería y Arquitectura, Ciencias de la Tierra, tesis profesional, $54 \mathrm{p}$.

Navarro-Santillán, D, Sour-Tovar, F., Centeno-García, E., 2002, Lower Mississippian (Osagean) brachiopods from the Santiago Formation, Oaxaca, Mexico: stratigraphic and tectonic implications: Journal of South American Earth and Sciences, 15, 327-336.

Ochoa-Camarillo, H., 1996, Geología del Anticlinorio de Huayacocotla en la región de Molango, Estado de Hidalgo: Universidad Nacional Autónoma de México, Facultad de Ciencias, División de Estudios de Posgrado, tesis de maestría, $91 \mathrm{p}$.

Ortega-Gutiérrez, F., Ruiz, J., Centeno-Garcia, E., 1995, Oaxaquia-A Proterozoic microcontinent accreted to North America to North America during the Late Paleozoic: Geology, 23, 1127-1130.

Pindell, J.L., 1985, Alleghanian recontruction and subsequent evolution of the Gulf of Mexico, Bahamas and Proto-Caribean: Tecton, 4, 1-39.

Rosales-Lagarde, L., 2002, Estratigrafía y Geoquímica de la secuencia volcano-sedimentaria paleozoica del noreste del Estado de Hidalgo: México, D.F., Universidad Nacional Autónoma de México, Posgrado en Ciencias de la Tierra, tesis de maestría, 89 p. 
Rosales-Lagarde, L., Centeno-García, E., Ochoa-Camarillo, H., SourTovar, F., 1997, Permian volcanism in eastern Mexico. Preliminary Report. II, Convención sobre la Evolución geológica de México y Recursos Asociados: IICT, Universidad Autónoma del Estado de Hidalgo-IGEOL, Universidad Nacional Autónoma de México. Libro-guía de las excursiones geológicas, excursión, 1, 27-32.

Rothwell, G.W., 1982, New interpretations of the earliest conifers: Review of Palaeobotany and Palynology, 37, 7-28.

Rothwell, G.W., Mapes, G., Mapes, R.H., 1997, Late Paleozoic conifers of North America: structure, diversity and occurrences: Review of Palaeobotany and Palynology, 95, 95-113.

Rothwell, G.W., Mapes, G., 2001, Barthelia furcata gen. et sp. nov., with a review of Paleozoic coniferophytes and a discussion of coniferophyte systematics: International Journal of Plant Sciences, 162, 637-677.

Rothwell, G.W., Mapes, G., Hernandez-Castillo, G.R., 2005, Cladistic relationships among the most ancient conifers (Voltziales): Taxon, 52, 733-750.

Sánchez-Zavala, J.L., Centeno-Garcia, E., Ortega-Gutiérrez, F., 1999, Review of Paleozoic Stratigraphy of Mexico and its role in the Gondwana-Laurentia connections: Geological Society of America Special Paper, 336, 1-16.

Silva-Pineda, A., 1987, Algunos elementos paleoflorísticos del Pérmico de la región de Calnali, Estado de Hidalgo: Sociedad Mexicana de Paleontologia Revista, 1, 313-326.

Silva-Pineda, A., Buitrón, S. B., Flores de Dios, A., 2000, Presencia de coníferas en el Pérmico (Leonardiano) de Calnali, Hgo., Patlanoaya, Pue. y Olinalá, Gro. $2^{\mathrm{a}}$ Reunión de Ciencias de la Tierra: GEOS, Unión de Geofisicos de Mexico A.C. Resumenes, 20, 302-303.
Silva-Pineda, A., 2003, Flora del Pérmico de Izúcar de Matamoros, Puebla, in Soto, L.A. (ed.), Ayala-Castañares: universitario impulsor de la investigación científica: Instituto de Ciencias del Mar y Limnologia UNAM, 303-309.

Sour-Tovar, F., Pérez, H.A., Quiroz-Barroso, S., Centeno-García, E., 2005, Braquiópodos y trilobite del Pérmico Inferior del Estado de Hidalgo, México: Revista Mexicana de Ciencias Geológicas, 22, 24-35.

Stewart, J.H., Blodgett, R.B., Boucot, A. J., Carter, A. J., Lopez, R., 1999, Exotic Paleozoic strata of Gondwanan provenance near Ciudad Victoria, Tamaulipas, Mexico. In Pages 227-252, Ramos, V. A., Keppie, J. D. (eds)., Laurentia-Gondwana connections before Pangea: Geological Society of America Special Papers, 336.

Stewart, W.N., Rothwell, G.W., 1993, Paleobotany and the Evolution of Plants: Cambridge University Press, Cambridge, 536p.

Vachard, D., Flores de Dios, A., Buitrón, S.B., Grajales, M., 2000, Bioestratigraphie par fusulines des calcaires carboniféres et permiens de San Salvador Patlanoaya, Puebla, Mexique: Geobios, 33, 5-33.

Visscher, H., Kerp, J.H.F., Clement-Westerhof, J.A., 1986, Aspects of Permian paleobotany and palynology. VI. Towards a flexible system of naming Paleozoic conifers: Acta Botanica Neerlandica, 35, 87-99.

Winston, R.B., 1984, The Upper Pennsylvanian conifer Walchia garnettensis; structure and affinities: Palaeontographica Abteilung B 194:97-108

Manuscript received: February 22, 2013.

Corrected manuscript received: April, 10, 2013.

Manuscript accepted: September 7, 2013. 